\section{Ind i litteraturen}

Knud Sønderby blev en af det 20 . århundredes populære og meget læste forfattere. Men hans vej ind i litteraturen var vanskelig. Forfatterens første roman Midt i en Jazztid, der skildrer en frigjort ungdom, blev enstemmigt afvist af samtidens anmelderkorps.

\section{Af cand.mag. Benni Bødker}

$\mathrm{K}$ nud Sønderby udviklede med årene en presseskyhed. Helst holdt han journalister og andre nysgerrige på behørig afstand, efterhånden som mængden af interesserede stadigt forøgedes. For Knud Sønderby (1909-1966) hørte til efterkrigstidens mest læste. Han var en velestimeret forfatter, på det nærmeste institutionaliseret ved at udkomme på det revitaliserede og atter førende Gyldendal, samt ikke mindst som medstifter af Det danske Akademi. Dertil oplevede han en folkelig bevågenhed, der bragte oplags- og læsertal op i efter danske forhold astronomiske højder. Billigbogsboomet i 1960'erne kom forfatterskabet til gode, og Sønderby kunne ride med på nyrealismens genopdagelse af 1930 ' ernes litteratur og ikke mindst den nye generation af ungdomsromaner (Klaus Rifbjergs Den kroniske uskyld, Leif Panduros Rend mig i traditionerne og Anders Bodelsens De lyse natters tid udkom alle i 1958).

Midt i en Jazztid, Sønderbys debutroman fra 1931, er nok den, der har oplevet det længste efterliv. Hjulpet på vej af
Knud Leif Thomsens noget ujævne filmatisering i 1969, er romanen siden forblevet i trykken. I 1999 blev den således nr. 10 i Politikens læserafstemning om "Århundredets danske roman" og seneste oplag udkom i 2000. Forfatterskabets popularitet og anerkendelse, der i dag betragtes som noget af en selvfølge, slører imidlertid det faktum, at Sønderbys vej ind i litteraturen ikke bare var vanskelig, men også at han ved udgivelsen af sine første romaner mødte en så enstemmig afvisning fra anmelderkorpset, at han hører til en af periodens mere udskældte danske forfattere. Det kan være vanskeligt at forstå i dag, hvor han både i litteraturhistorier og undervisningen betragtes som en selvfølgelig klassiker.

Men i Knud Sønderbys efterladte papirer på Det Kongelig Bibliotek (UT. 505) kan man læse hele den dramatiske beretning. For nok var Sønderby pressesky, men han var bestemt ikke pressefjendsk. Hans officielle forfatterskab er en lille eksklusiv samling romaner, teaterstykker og essaysamlinger, men ved siden af udfoldede han en journalistisk virksomhed af imponerende omfang. Og ikke mindst samlede han minutiøst udklip om sig selv fra danske og udenlandske aviser, som behørigt blev arkiveret i en række store scrapbøger, der nu indgår i de efterladte papirer. ${ }^{1}$ I begyndelsen må det have været deprimerende at samle, men scrapbøgerne giver i dag et enestående indblik i omstændighederne omkring Sønderbys debut og ikke mindst modtagelseskritikken, hvilket udgør genstandene for følgende gennemgang. ${ }^{2}$

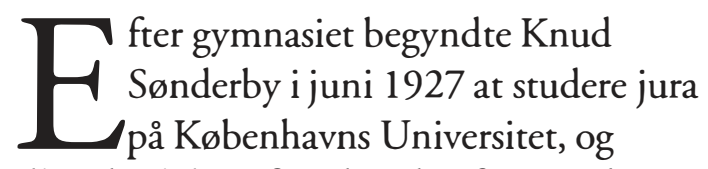
allerede i løbet af studietiden forsøgte han at skrive noveller. Disse tidlige noveller er 


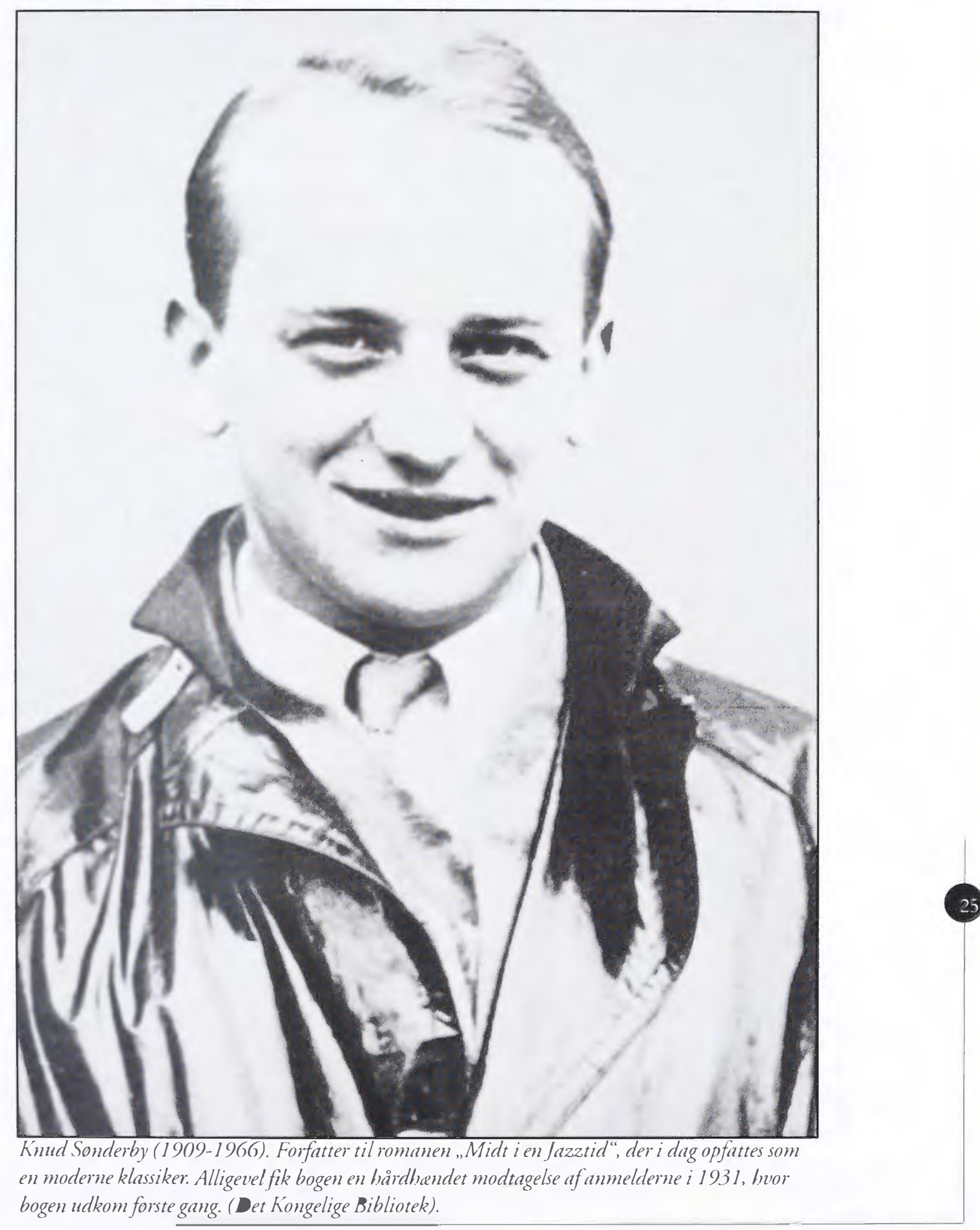


formodentlig gået tabt, ${ }^{3}$ men et glimt af forfatterskabets begyndelse kan fås $\mathrm{i}$ Sønderbys lille skitse i Vild Hvede fra maj 1931, der blev hans litterære debut. Vild Hvede var et tidsskrift for ung litteratur under redaktion af Viggo F. Møller, der var forfatter af sære fortællinger og en kort overgang gift med Tove Ditlevsen. Vild Hvede eksisterede 1930-51 og trykte bidrag af adskillige af tidens store forfattere side om side med for længst glemte debutanter. Bladet var en fortsættelse af Klinte (192526) og udviklede sig senere til det stadigt eksisterende Hvedekorn. Sønderbys bidrag er en lille skitse eller shortstory, der hedder "Baggaardsbørn". ${ }^{4}$ Trods titlen er det ikke dyster socialrealisme. Den ildelugtende baggård og de fattige forhold i et arbejderkvarter beskrives, men miljøet er kun antydet og underordnet. Historiens egentlige ærinde er den spirende romantik mellem en dreng på 15 år og en pige på 14, der sidder i en vindueskarm mellem 3. og 4. sal. De er endnu børn, men kender til de voksnes erotik og vil gerne udforske den, uden egentlig at vide, hvad de skal stille op med den. Et udateret udklip uden kildeangivelse forrest i scrapbogen vidner om, at Sønderbys bidrag blev fremhævet i en kortfattet anmeldelse af tidsskriftet.

I løbet af 1930 fik novellerne en form for litterær bevågenhed, da den unge kritiker Frederik Schyberg fik dem at læse. Det skyldtes i første omgang en misforståelse, der er meget sigende for stud.jur. Sønderbys manglende kendskab til tidens litterære miljø. Han troede at have set Schyberg i universitetes frokoststue på Studiegården og bad derfor en studiekammerat, der boede på samme vej i Charlottenlund som Schyberg, om at give ham novellerne, så han kunne læse dem. I virkeligheden var det kritikeren Peder
Hesselaa, Sønderby troede at kende. ${ }^{5}$

Frederik Schyberg (1905-50)

havde siden 1929 været tilknyttet den konservative avis Nationaltidende/Dagens Nyheder. Som anmelder var han primært æstetisk indstillet og forsøgte at holde politik og livsanskuelse ude af sin kritikervirksomhed, hvilket dog ikke afholdt ham fra iblandt at være moralsk og sædelig i sin kritik. Han var først og fremmest teateranmelder, men skrev også om moderne litteratur og var en af de første til at tage filmen alvorligt. Som led i sit arbejde på en doktordisputats om Walt Whitman, skrev han en bog om Moderne amerikansk Litteratur (1930), hvor han som en af de første i Danmark omtalte F. Scott Fitzgerald og Ernest Hemingway." Schyberg regnede den anti-puritanske Hemingway for en af efterkrigstidens vigtigste forfattere, men mente også, at han var et sygdomstegn, fordi han var dekadent og altså repræsenterede en kultur i undergangsfasen. ' Schyberg var en kritiker, der ikke veg tilbage for den nye litteratur, og han dyrkede gerne sin pædagogiske åre ved at optræde som privat konsulent for vordende og allerede etablerede forfattere. Det kom Sønderby til gode, og hans noveller blev forsynet med en anbefaling skrevet på Nationaltidendes papir, som han kunne sende med rundt til forlagene. Brevet, der nu findes i scrapbøgerne, er dateret 12. november 1930 og lyder:

"Den unge Knud Sønderby har bedt mig om en Udtalelse ang. hans første Noveller. De har interesseret mig meget at læse, fuldendte er de selvfølgelig langtfra, men i deres komplette Uaandelighed afspejler de en bestemt side af moderne Ungdom, som det er en Velgerning at se afspejlet, også på dansk. Det er ikke en ung Poet der her taler, det er en ung Mand af $\mathrm{i}$ Dag, - og man kan i hans Småfortællinger 


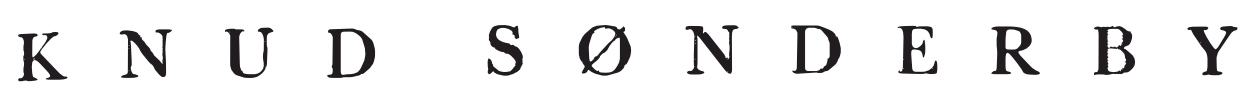 \\ MIDT I EN JAZZTID}

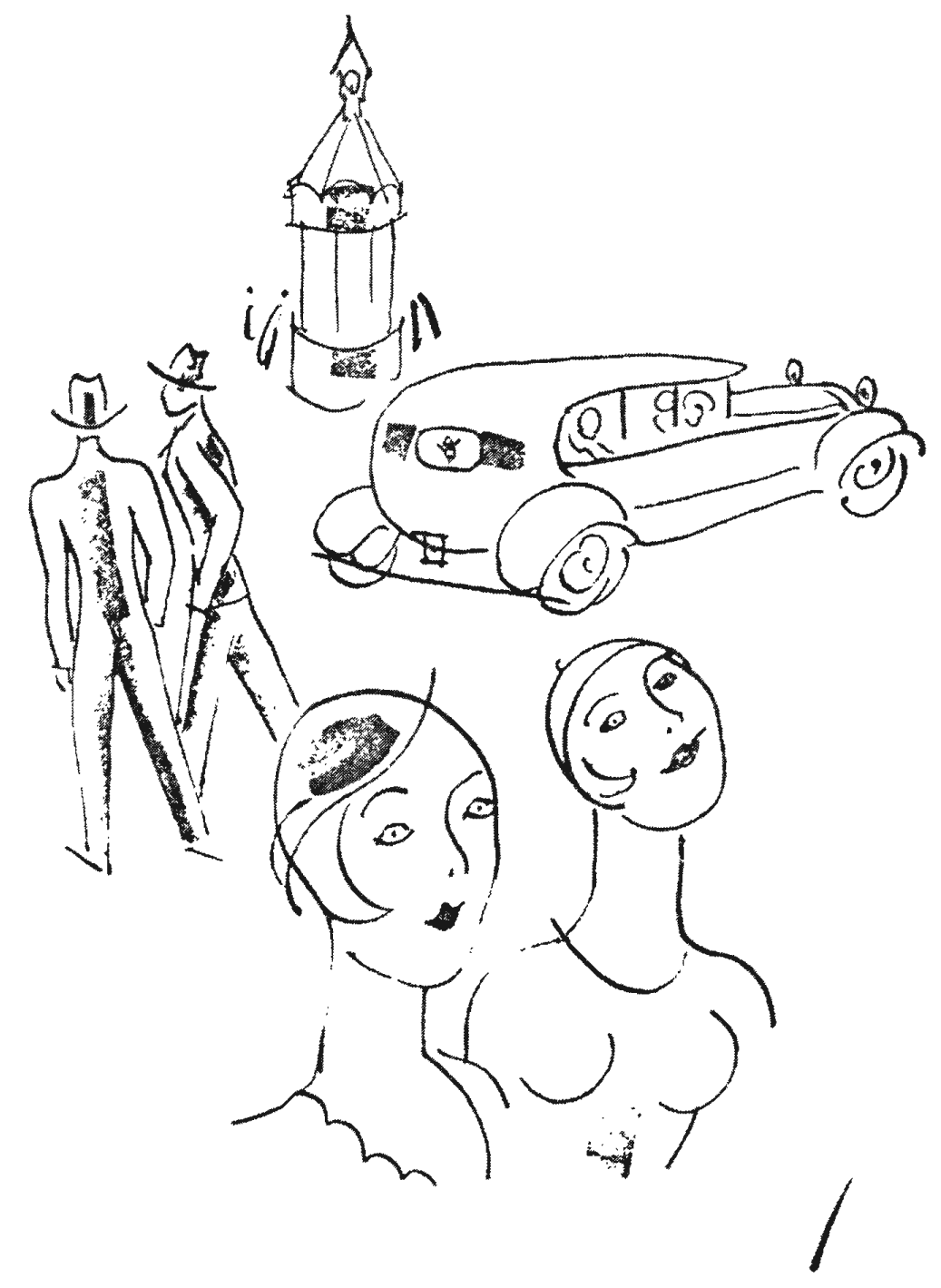

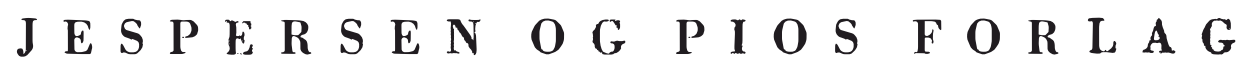

Omslaget til 1. udgaven af ". Midt i en Jazztid“ er med Axel Nygaards kongeniale illustration. Bogen blev med det samme en salgssucces. Forste oplag var udsolgt på 14 dage. (Det Kongelige Bibliotek). 
finde Udtryk for en lignende Efterkrigspsykologi, som har betinget f.Eks.

Hemingways internationale Succes. Jeg synes disse Historier fortjener at udgives, - de vil sikkert finde Læsere."

Det kan betegnes som Sønderbys første anmeldelse, og den er interessant ved sammenligningen med Hemingway, og ved at Schyberg lagde vægt på, at novellerne var "uåndelige" og afspejlede en bestemt generation. Han mente altså, at Sønderby skrev mere realistisk og mindre idealistisk end andre forfattere om tendenser i det moderne Danmark, som ikke havde været beskrevet kunstnerisk før.

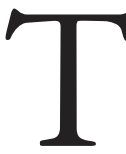
rods hjælpen fandt novellerne ikke nogen forlægger, men opmuntret af Schyberg besluttede Sønderby sig for $i$ stedet at skrive en roman. Han handlede hurtigt: manuskriptet til Midt i en Jazztid blev til i løbet af marts 1931. I april diskuterede han den igennem kapitel for kapitel med Schyberg, og i maj var romanen klar til at sendes ud til forlag, igen forsynet med en anbefaling af Schyberg dateret 9 . maj 1931:

"Uden Gran af Pretention, uden Anelse af det intellektuelle Skaberi, som præger vore andre Forfattere af de yngre Aargange - har en ung Student her fortalt om sig selv og sine Jævnaldrende og derved givet et Billede af det "unge Danmark", det unge almindelige Danmark midt i en Jazztid, som forekommer mig meget værdifuldt. Ikke mange unge Mænd el. unge Kvinder vil undlade at genkende meget af sigselv og af deres Nærmeste i Knud Sønderbys Skildringer $[\ldots]$.

"Uden kunstneriske Kvaliteter er Knud Sønderbys Skildringer med al deres store Nøgternhed jo langtfra. Meget i hans Sind tyder på, at der her er en virkelig
Fortæller på Vej, og allerede denne hans første Bog synes mig at være ligesom et dansk Sidestykke til Hemingways amerikanske Romaner og til Sigurd Hoels ypperlige norske Ungdomsroman "Syndere i Sommersol" [...].")

Ligheden med Hemingways debutroman The Sun Also Rises (1926) var noget anmeldere og senere kritikere hæftede sig ved, iblandt grænsende til beskyldninger for plagiat. Sønderby påstod selv, at han først læste Hemingway på Schybergs opfordring efter at han havde skrevet sin roman. ${ }^{10}$ Det virker nu ikke helt rimeligt, eftersom Sønderby i det mindste må have kendt til Hemingway siden anbefalingen fra november 1930. Når Sønderby så hyppigt i samtiden blev sammenlignet med Hemingway, skal svaret nok findes $i$, at anmelderne så ham som udtryk for en tendens, de ikke brød sig om, og derfor gerne ville bortforklare. Den nemmeste afvisning var at sige, at Sønderbys kyniske ungdom blot var udtryk for en forfatter, der var for inspireret af det nyeste fra USA. Til gengæld virker det plausibelt, at Schyberg kan havde gjort Sønderby opmærksom på Fitzgeralds første novellesamling Tales of the Jazzage (1922), hvorfra han kan have făet inspiration til sin egen romantitel.

Romanen blev endelig antaget $\mathrm{i}$ begyndelsen af juni på forlaget Jespersen $\&$ Pio med en meddelelse om at romanen "kun vil opnaa et ringe Salg, da den kun vil blive forstaaet og gouteret af det faatallige, litterært kyndige Publikum", men at dens kunstneriske kvaliteter berettigede den til udgivelse. ${ }^{11} \mathrm{Og}$ for at demonstrere, at betænkelighederne var oprigtigt ment, lod forlaget satsen bryde, da romanens første oplag på kun 1.200 eksemplarer var trykt. Da den udkom 23. september 1931 var den tilegnet Frederik Schyberg. Forlaget måtte 


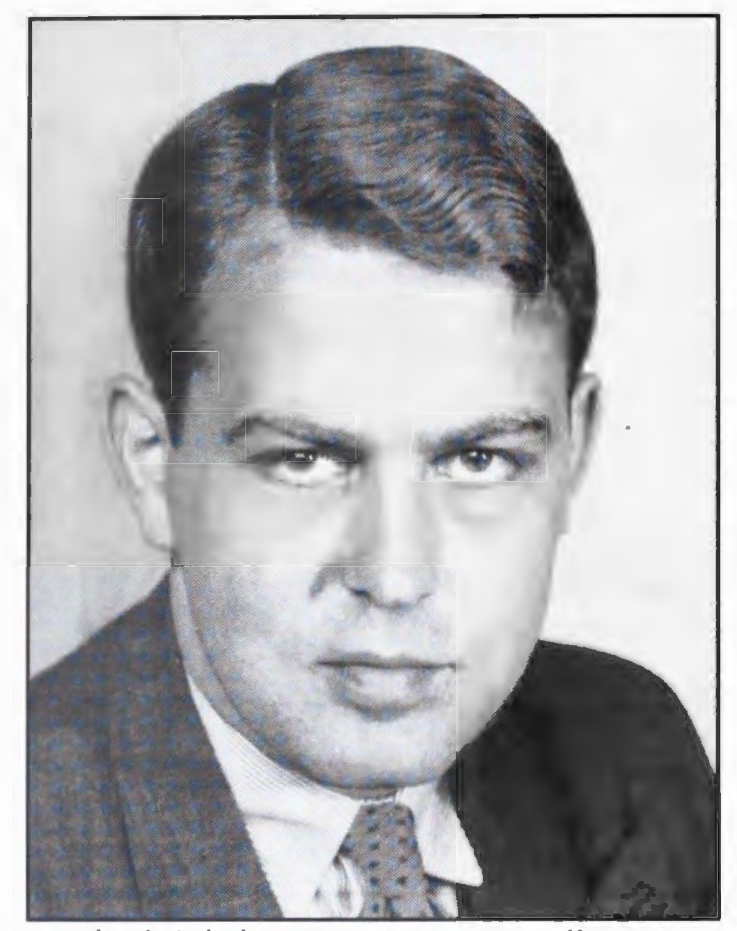

Frederik Schyberg (19()5-5()) war tilknyttet Nationaltidende/Dagens Nyheder. Han forsynede manuskriptet til „Midt i en lazztid“ med en anbefaling, da romanen blen sendt ud til forlagene. (Det Kongelige Bibliotek).

skyndsomst satte bogen en gang til, for trods - eller måske netop på grund af anmeldernes kritiske indstilling, blev romanen noget af en chokscller. Forste oplag var udsolgt på 14 dage, yderligere tre oplag på hver 1.100 eks. blev trykt inden året var omme, og allerede året efter blev den også oversat til svensk, hvor den kom i tre oplag. Det blev hurtigt en beromt og berygtet bog, hvilket forlaget naturligvis ikke undslog sig for at spille på i smarte annoncer sat $i$ moderne funkisstil, som Sonderby stolt har indklaxbet (men igen uden kildeangivelse):

"Knud sonderby Midt i en Jazztid er Bogen om de Unge af ldag og Imorgen; Bogen, der berommes og fordømmes; Bogen alle taler om; - Bogen der sxelges i Oplag paa ()plag!"
B egejstringen var der ingen spor af hos hovedstadens anmeldere. Midt i en lazztid udkom ikke til stående ovationer, i stedet tegnede der sig i modtagelsen på tvaers af alle fronter en faelles forargelse. Den danske daghladskritik befandt sig i begyndelsen af 1930'erne i en overgangsfase. Livsanskuelsesdebatten fra midten af 20'erne var ved at ebbe ud, og politiseringen havde endnu ikke sat ind for alvor. Resultatet var en kritik, der var optaget af både moralske og politiske sporgsmål, men i mindre grad var interesseret i litteraturteoretiske vurderinger. I en nye litteratur blev last og bedomt efter sin holdning og tendens. Mange af tidens anmeldere var prieget af både det moralske og det politiske, og deres kritik kan derfor forekomme inkonsistent og selvmodsigende. I erfor optrådte socialdemokraten Julius Bomholt lige så moralsk bornert og sxedelig som den konservative Henning Kehler, og derfor var den konservative Hakon Stangerup iblandt lige så fordomsfri som ast eten lom Kristensen.

\section{Man kan heller ikke helt regne} med avisernes tilhorsforhold. I 30'erne eksisterede det gamle firebladsystem stadig, hvor nexsten alle storre byer havde mindst ét dagblad for hvert politisk parti, men i stadigt stigende grad blev kulturstoffet skilt ud fra det ideologiske. P’å det radikale Politiken sad eks. den astetiske anmelder lom Kristensen, ligesom Hans Brix ikke var på det konservative I Jagens $N y$ heder af politiske årsager. P’å den anden side var der stadig rester af det gamle system. Henning Kehler på Berlingske Tidende var absolut national og kristen, mens Social-1)emokratens Julius Bomholt var manden, der tegnede socialdemokratiets kulturpolitik.

Anmelderne afviste alle som en 
Midt i en Jazztid, fordi de var forargede over dens skildringer af den moderne ungdom, deres moral, vaner og opførsel. Det var først og fremmest erotikken og ungdommens driverliv, der provokerede, og ikke overraskende udviste Henning Kehler og Julius Bomholt den stærkeste moralske anfægtelse. Henning Kehler (1891-1979) var oprindeligt radikal og skrev i Politiken, men sommeren 1925 foretog han med bogen Kampen for Livsanskuelse et opgør med radikalismen og blev fortaler for kristendom og konservatisme. Han kom via Kristeligt Dagblad til Berlingske Tidende, hvor han anmeldte ud fra et moralsk, konservativt og nationalt fundament. Kehler hørte til de mest subjektive og usaglige af periodens anmeldere, der ikke veg tilbage for personangreb eller uvederhæftige beskyldninger. ${ }^{12}$

For Henning Kehler var der ikke tvivl om at Sønderbys roman gav et korrekt og næsten dokumentarisk udtryk for en beklageligt stor del af den unge generation, der var kendetegnet ved at være forlystelsessyge og seksuelt uhæmmede. Trods bogens rå tone mente han dog også at den var moralsk, "Ikke ved det, den direkte siger, slet ikke ved nogen paahæftet Morale. Men ved det, den aabent vedgaar." ${ }^{13}$ Romanen vedgik ifølge Kehler, at tidens ungdom ikke var lykkelig, på trods af at de levede uden den ældre generations hæmninger. Han tillagde altså romanen en vis kritisk indstilling, men mente også, at dens frisprog var uacceptabelt. Ikke - som han skrev - fordi han var snerpet, men fordi:

"visse Ord virker helt anderledes paa Tryk end i det talte Sprog. Den slaviske Realisme er overhovedet ikke Realisme, men Mangel paa Evne til at tage Illusionen, dette $i$ al Kunst - enten det drejer sig om en Tragedie eller et Kirkespir - saa nødvendige Element med i Betragtning."
Kehler påtalte, at romanens realisme ikke var kritisk nok. Han gav udtryk for, at realisme ikke blot bør være virkelighedsgengivelse, men også en idealistisk vurdering af virkeligheden. Han kritiserede derfor, at Sønderby ikke havde lagt nok afstand til sit emne, og anmeldelsen sluttede med en bøn til censurens genindførelse:

"Undertiden maa en Kritiker i vore Dage mindes Censurens Velsignelser. Censur, enten den er lovfæstet eller kun støtter sig til Smagens uskrevne Lov, lærer Skribenterne at gøre sig Umage og at overvinde Vanskeligheder. Censur er en Forudsætning for Stil. Naar alt er tilladt er alt let, men sandelig om alt er godt."

$\mathrm{J}$ ulius Bomholt (1896-1969) var teolog og senere Danmarks første kulturminister. Han var kommet til Social-DemokraTen i 1931 fra en mindre provinsavis og havde netop udgivet den første marxistiske litteraturhistorie i Danmark, Dansk Digtning fra den industrielle Revolution til vore Dage (1930). Hans anmeldelser var programmatiske og ville fremme en arbejderkultur, hvis særlige kulturideal skulle være socialistisk. Året efter formulerede han sit program i bogen Arbejderkultur (1932), hvor han skrev, at tidens tiltagende fokusering på det erotiske var et tegn på det borgerlige samfunds forfaldsperiode. ${ }^{14}$ Det viste sig i anmeldelsen af Sønderby, hvor han om bogens borgerlige ungdom vrængede, "Erotisk set indretter man sig paa Planøkonomi. Hvis det "kribler" i Nerverne, arrangerer man sig for en Nat med et Pigebarn. Begreber som "Præventiver" og "Menstruation" hører med til Børnelærdommen."15

Betegnende nok er det en overdrivelse af romanens erotiske frigjorthed. 
Der er ingen eksempler på tilfældige seksualpartnere, og hverken præventiver eller menstruation omtales direkte i romanen. Men det er karakteristisk, at Bomholt overdrev graden af ungdommens frigjorthed eller mangel på moral for at markere sin afstandtagen. "' Han sammenlignede desuden romanen med Johannes Jørgensens og Viggo Stuckenbergs drømmere i symbolistromanerne fra 1890 'erne. En sammenligning, der ikke faldt ud til den samtidige generations fordel:

"Og saa Knud Sønderbys jazzende, bilkørende og whiskydrikkende Ungdom! Denne Ungdoms Domæne strækker sig fra Strandvejens Velhavervilla til "Valencia". Drømmen er erstattet af en blasert, lidt verdensmandstræt ${ }^{17}$ Erkendelse af en temmelig kedelig Virkelighed. Man interesserer sig for Bilmærker og Greta Garbos erotiske Teknik, og iøvrigt er det Dagens Problem, om man i det hele taget gider noget."

Greta Garbos erotiske teknik er igen noget Bomholt havde opdigtet for at gøre de unge værre, end de blev skildret i romanen. Det tyder på, at han snarere forholdt sig til en tendens i tiden, end til den bog, han skulle anmelde. Hans litteraturopíattelse baserede sig på, at litteraturen skulle være opbyggelig, kollektivistisk og realistisk, dvs. handle om typer snarere end individer og om arbejdere snarere end borgerskab. ${ }^{18}$ Han konkluderede derfor, at Sønderbys roman ikke havde anden værdi for arbejderne end som et skræmmebillede af et overflødigt og arrogant borgerskab.

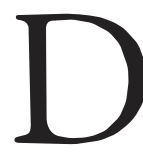
et kan ikke undre, at de to enlige repræsentanter for den ældste generation var kritiske. Freilif Olsen (1868-1936), der på dette tidspunkt var medredaktør på Ekstra Bladet efter i mange år at have været enerådende, var kun perifert litteraturanmelder. Han afviste kort og overfladisk den moderne ungdom og dermed også bogen. ${ }^{19}$ Litteraturvidenskabsmanden Hans Brix (1870-1961) indrømmede Sønderby visse håndværksmæssige kvaliteter, men erklærede ellers, at "Danske Forældre maa gyse" over den kyniske, ligeglade og erotiske ungdom, og han konkluderede:

"Lægemidlet maa for den

nuværende Slægt som for de ældre blive alvorligt Arbejde. Men her er Ulykken den, at Sporten skyder sig imellem. Den er nemlig Arbejde - den bruger Kræfterne - men det er ikke alvorligt Arbejde. Sporten er ifølge sit Væsen Illusion og gold." ${ }^{20}$

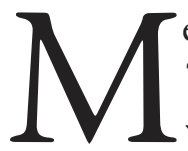
est overraskende er det vel at Tom Kristensen (1893-1974) var at finde i det kritiske kor. Han var i 1931 vendt tilbage til Politiken som førsteanmelder efter at have udgivet romanen Herverk (1930), hvor han selv skildrede jazztidens fænomener. Han var en af periodens mest åbne anmeldere, der introducerede til tidens internationale forfatterskaber, ikke mindst fra den angelsaksiske verden, og var erklæret programløs som impressionistisk anmelder. Ikke desto mindre tilsluttede Tom Kristensen sig Brix' dom, når han om romanhovedpersonens melankoli skrev, at "det slaar Læseren, at herregud, Bæstet kan jo bare tage og bestille noget, saa er det Problem løst. Disse Piger og disse Drenge er det meget let at kurere."21 Han var ikke villig til at se ungdommen som andet end tanketomme og overfladiske. En forklaring på reaktionen ligger $i$, at Kristensen var overbevist om, at Sønderby havde forlæst sig på Hemingways første roman (hvis titel Kristensen dog huskede forkert). 

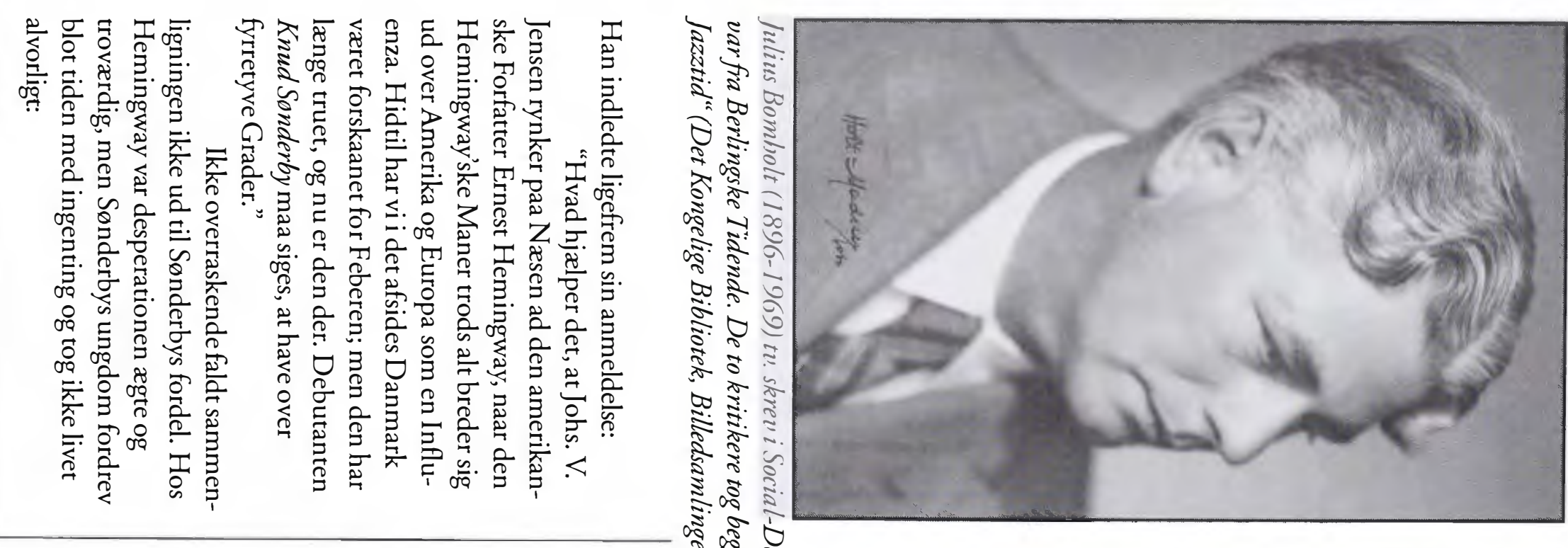

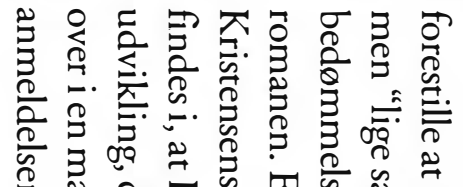

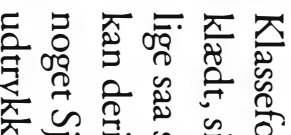

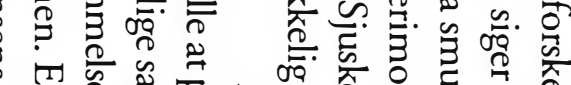

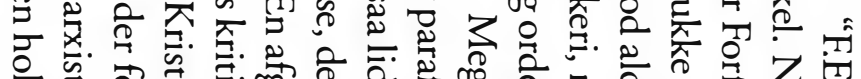

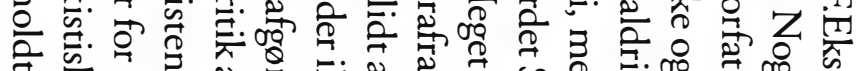

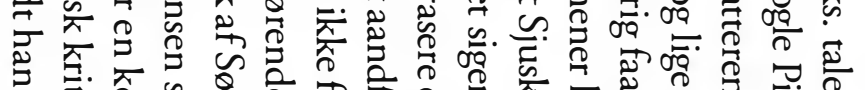

可: 不

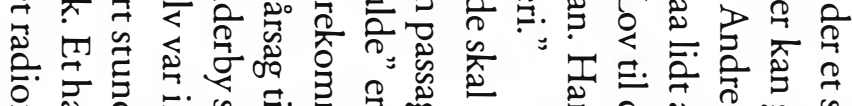

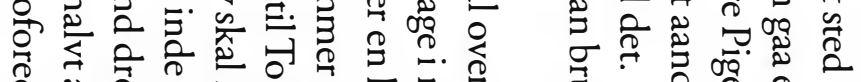

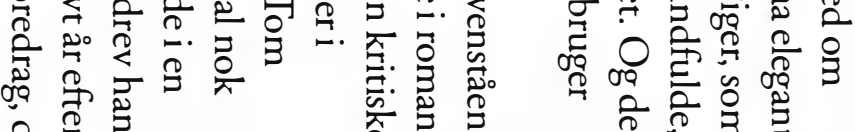

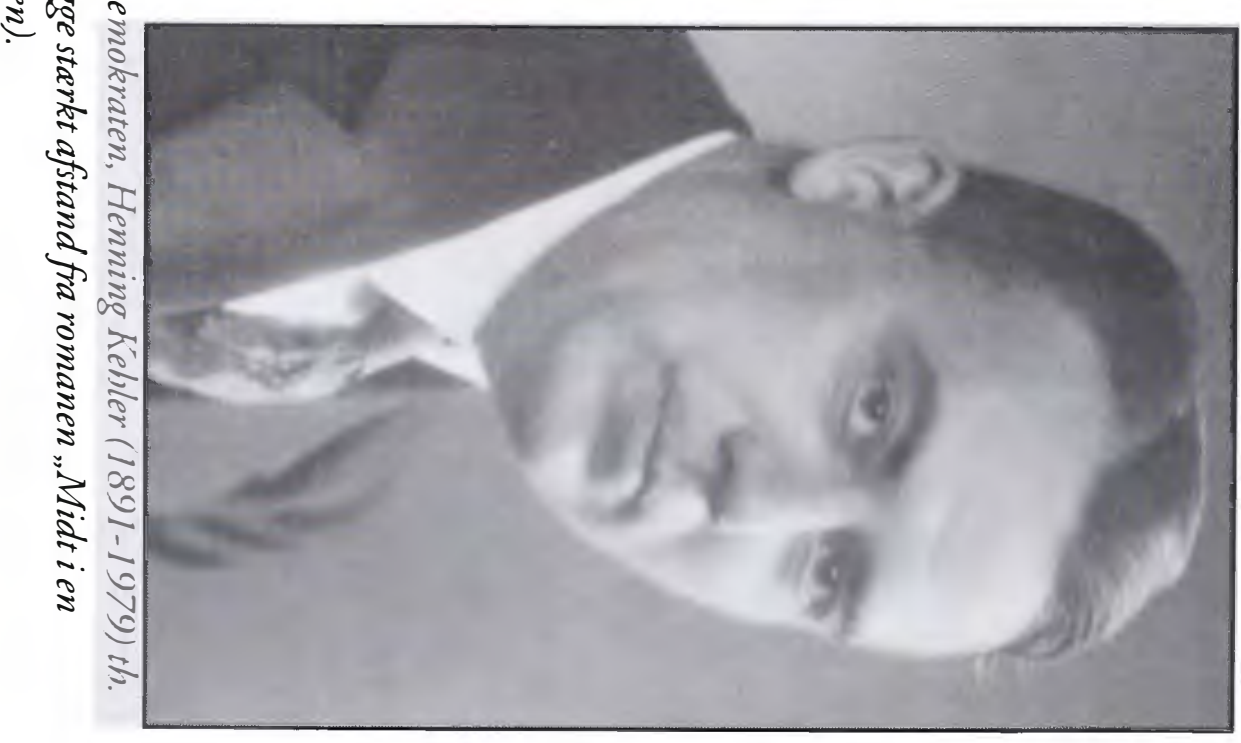


blev udgivet under titlen Kunst, Økonomi, Politik (1932), hvor han kritiserede den kunst, der ikke afspejlede den moderne krise, og opfordrede den unge generation til at forstå de økonomiske forhold, "Ungdommen maa altsaa blive politisk." 22

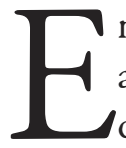
ndelig blev Knud Sønderbys roman anmeldt af en anden romanforfatter, der også havde markeret sig ved sine skildringer af samtiden, nemlig den reaktionære Jacob Paludan. Sønderby huskede senere hans negative anmeldelse således: "En ung mand kommer jazzende ind på scenen", skrev Paludan med et ubehag, der nærmede sig væmmelse og viste, hvor lidt velkommen jeg var." ${ }^{23}$ En sådan anmeldelse ligger imidlertid ikke i scrapbøgerne på Det Kongelig Bibliotek, og den er heller ikke omtalt i nogen bibliografi, men Paludan skrev på dette tidspunkt mest i Nationaltidende. ${ }^{2+}$ At Sønderby ikke har husket forkert, bekræftes dog af et upubliceret brev fra Jacob Paludan til bogsamleren Peter Christiansen dateret april 1970, der findes i en anden samling på Det Kongelige Bibliotek. Paludan sendte ham sit eksemplar af Midt i en Jazztid og skrev: "Men hverken straks eller senere har Bogen talt udpræget til mine særlige Fornemmelser, saa Tabet vil glemmes. Min Anmeldelse i sin Tid paaførte mig vist Sønderbys livsvarige Had, hvilket viser, hvor prekært det i meget smaa Lande er med Akademier." $2 \varsigma$

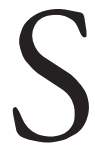
amlet må man konstatere, at anmelderne kun i ringe grad behandlede Knud Sønderbys debutroman, men snarere forholdte sig til den ungdom, som romanen skildrede. Eftersom romanen ikke lagde afstand til de unge, måtte den opfattes som kunstnerisk fejlslagen. Den positive vurdering af Sønderby i efterkrigsårene skyldtes ikke, at anmelderne ændrede mening eller indså, at de havde fejlbedømt forfatterskabet. Det var en ny generation af kritikere, der var med til at kanonisere romanerne. Forklaringen er formodentlig den, at Sønderby i løbet af efterkrigsårene ikke længere blev betragtet som en "farlig" forfatter. Hans romaner kunne nu ses med en vis distance som et historisk fænomen, der ikke provokerede ved deres skildringer af samtiden. Men for de samtidige anmeldere var det ikke muligt at anskue romanerne som primært æstetiske konstruktioner. For dem gav Sønderby først og fremmest udtryk for en holdning til samtidens fænomener, kun i anden række var han en skønlitterær forfatter. Litteraturen var ikke et neutralt område for 1930'ernes anmeldere, og de opponerede både imod Sønderbys portræt af tiden og imod selve tiden.

Årsagen til at Sønderbys romaner blev opfattet så provokerende skal findes $\mathrm{i}$, at han skrev om moderniteten og om et Danmark, der gennemgik en brydningstid. I Danmark i årene efter 1. verdenskrig var den største enkelte omvæltning nok amerikaniseringen, der gav sig udslag i massekultur, kvindefrigørelse og andre radikale forandringer, der blev oplevet både som en krise og som en udfordring. De radikale forandringer bidrog til følelsen af en generationsmodsætning, hvilket igen skærpede standpunkterne. Eftersom de fleste af Sønderbys anmeldere var stærkt kritiske overfor amerikaniseringen, blev han gjort til skydeskive, fordi han skrev om det, der for dem stod som det værste i denne modernitet: den frigjorte ungdom, der hverken havde respekt for den ældre generation eller disses moral og konventioner. 
Kritilenen FREIERIA SCHFBERT; tilengnten

„Midti en Jazztid“ udkom 23. september 1931 og var tilegnet Frederik Schyberg. (Ill. fra bogen).

Noter:

1 Det er UT. 505. IV. 2. al der i det følgende vil blive undersøgt. Kapslen indeholder en scrapbog med opklæbede artikler og papirer i forbindelse med den litterære debut.

2 Sønderby har selv (med variationer) beskrevet sin debut i essayene "Tredive år efter" og "Midt i en jazztid" (begge i Knud Sønderby: De blå Glimt. Gyldendal, 1964), "Mennesket Frederik Schyberg" (i Knud Sønderby: De danske havne. Gyldendal, 1969) samt i et interview (i Niels Birger Wamberg: Samtaler med danske Digtere. Gyldendal, 1968).

3 De findes heller ikke på Det Kongelige Bibliotek, når undtages nogle fragmenter, der har overlevet, fordi de er benyttet som kladdepapir til en udgave af manuskriptet til Midt i en Jazztid (NKS 2575. $2^{\circ}$ ). Et alternativt manuskript til romanen findes i de efterladte papirer, UT. 505. III. 1.

4 Knud Sønderby: "Baggaardsbørn", in Vild Hvede, årg. 5, nr. 7, 1931.

5 Wamberg 1968: 101f.

6 Johannes V. Jensen præsenterede også Hemingway i Danmark på samme tid. Det skete i en kronik i Politiken 30. maj 1930 (genoptrykt i Johannes V. Jensen: Retninger $i$ Tiden. Gyldendal, 1930). Tom Kristensen, der ellers var tidens store anbefaler af engelsksproget litteratur, omtaler tilsyneladende ikke Hemingway før i sin anmeldelse af Knud Sønderbys debutroman.

7 Det minder en del om Johannes V. Jensens bedømmelse. Han fremhævede Hemingway som en moderne forfatter, der skæmmes af drikfældighed og erotisk frisprog. Om den første roman hedder, at den "gør Indtryk af at være komponeret over Kaferegninger som historisk Tekstmateriale." (Jensen 1930: 104). Sammen med James Joyce og D. H. Lawrence făr Hemingway bedømmelsen: "Hele Litteraturarten leder Tanken hen paa syge Hunde." (Jensen 1930: 109). 8 Knud Sønderbys efterladte papirer (KB UT. 505. IV. 2. a1).

9 Knud Sønderbys efterladte papirer (KB UT. 505. IV. 2. a1). Sigurd Hoels Syndere $i$ Sommersol (1929, da. 1944) skildrer en gruppe unges frigjorte sommer, der blot resulterer i nye konflikter.

10 Det sker dels i et interview kort efter udgivelsen i Ugeblad for Studerende, 30. oktober 1931, og dels senere i 1964 i essayet "Midt i en jazztid" (optrykt i Sønderby 1969).

11 Brev fra Jespersen \& Pios Forlag 3. juni 1931 i Knud Sønderbys efterladte papirer (KB UT. 505. II).

12 En bedømmelse der går igen hos de fleste, 
der har beskæftiget sig med periodens anmeldere, eks. "Kehler er en mand med stærke antipatier, som han dækker bag en arrogant sikkerhed møntet ud i rigoristiske domme og fordomme." (Ole Hyltoft Petersen: "30'ernes kulturdebat", in Hans Hertel (red.): Tilbageblik på 30'erne.

Aschehoug. 1967, 2. udg. 1997, s. 182).

13 Her og i det følgende citeres fra Kehlers anmeldelse i Berlingske Tidende 1. oktober 1931.

14 Julius Bomholt: Arbejderkultur. Forlaget Fremad, 1932, s. 23.

15 Her og i det følgende citeres fra Bomholts anmeldelse i Social-Demokraten 9. oktober 1931.

16 "Bomholts holdning til de stærkt erotiske boger må ses i sammenhæng med, at han opfattede sin anmeldergerning som et led $\mathrm{i}$ klassekampen, som et bidrag til, at en hidtil underkuet befolkningsgruppe med dens sunde og livsfrodige kultur kunne sejre." (Hyltoft Petersen 1967: 186)

17 Da Bomholt lod sin anmeldelse genoptrykke mildnede han anmeldelsen ved på dette sted at indsætte: "- men unægtelig ærlig, omsvøbsfri -" (Julius Bomholt: Før Uvejret. Gyldendal, 1947, s. 115).

18 Bomholt 1932, s. 160 f.

19 Det skete i Ekstra Bladet 24. september 1931.

20 Brix anmeldte i Dagens Nyheder 27. september 1931

$21 \mathrm{Her}$ og i det følgende citeres fra Tom Kristensens anmeldelse i Politiken 26. september 1931.

22 Tom Kristensen: Mellem Krigene. Gyldendal, 1946, s. 108.

23 Sønderby 1969, s. 10f.

24 Børge Benthien: Jacob Paludan. En bibliografi. Gyldendal, 1980 og Dan Hellum: Knud Sonderby. Danmarks Biblioteksskole, 1976.

25 NKS 5129. $4^{\circ}$ 